\section{BA Institute of \\ yk Business Administration \\ तर Karachi \\ Leadership and Ideas for Tomorrow}

Article 3

Volume 4 Issue 2 July-December 2009

$1-7-2009$

\title{
Can China save Capitalism
}

Javed A. Ansari

Institute of Business Management, Karachi

Follow this and additional works at: https://ir.iba.edu.pk/businessreview

Part of the Comparative Politics Commons

cC) (i)

This work is licensed under a Creative Commons Attribution 4.0 International License.

\section{Recommended Citation}

Ansari, J. A. (2009). Can China save Capitalism. Business Review, 4(2), 21-36. Retrieved from https://doi.org/10.54784/1990-6587.1329

This article is brought to you by iRepository for open access under the Creative Commons Attribution 4.0 License and is available at https://ir.iba.edu.pk/businessreview/vol4/iss2/3. For more information, please contact irepository@iba.edu.pk. 


\title{
ARTICLE
}

\section{Can China Save Capitalism}

\author{
Javed A. Ansari \\ Institute of Business Management, Karachi
}

\begin{abstract}
This paper assesses China's Potential as global Capitalism's Systemic hegemony replacing America. It outlines the internal constraints that restrict China's capacity to serve as a global systemic hegemon in the foreseeable future with special emphasis on the nature of the Chinese political system and its capacity both for sustaining the level of economic growth that has occurred since the launch of the 'Four Modernizations' programme in 1978 and for articulating policies for the emergence of China as a global hegemon.
\end{abstract}

Key words: China, Capitalsim, hegemony, state party relationship

\section{Can China Save Capitalism?}

The credit crisis of 2007-2009 has revitalized the debate about the durability of US global hegemony. Since at least the end of the Second World War America has served as global capitalism's principle authoritative organizer - its armed forces guarantee the continued expansion and survival of global capitalist rule. American norms, procedures and transaction forms increasingly serve as standards for structuring capitalist regulation regimes throughout the capitalist world. During much of the previous six and a half decades it is buoyant American demand which has ensured relatively long upturns in the global business cycle and the corresponding brevity and shallowness of global capitalist recessions.

Since at least the mid 1970s many authors have argued that America's ability to serve as global capitalism's hegemonic power cannot last long. America now accounts for about 4 percent of the world's population and this share will probably be halved by the end of the century. America's share of global GDP measured in purchasing power parity terms has declined from about 50 percent in the late 1940 s to about 21 percent today. America's savage military assaults on poor, destitute countries have usually lead to humiliating defeats and endemic chaos for America — North Korea, Cuba, Vietnam, Cambodia, Laos, Mozambique, Lebanon, Iraq, Afghanistan ad infinitum.

Most importantly the buoyancy of American consumer demand exacerbates the fundamental structural weaknesses of the American economy reflected in its massive fiscal and current account deficits. Therefore the time may soon come when America will have to relieve herself of "the white man's burden" 
Can this burden be shifted to yellow shoulders? The first part of this paper will present the views of those authors who believe that China can replace America like America replaced Britain in the twentieth century - as the new global capitalist hegemony. The second part will identify some internal obstacles which may prevent China from playing this role. The concluding section assesses these arguments.

\section{Global Capital Expects China to do Her Duty.}

The 2007-2009 credit crunch that emerged in America and much of Europe is usually attributed to a decline in non financial investments, a build up of corporate savings and an insufficient long term recovery of profits from the troughs of the 1970s. But West Europe and America have now been joined by what are called "the newly industrializing countries" as important engines of capitalist growth. The scope of the circuit of capital has expanded enormously since the 1970s and the volume of profit generated by capitalist investment has increased massively even if rates of profit in the old capitalist core economies remain below the peaks achieved in the 1960s. This means that new capitalist core regimes are beginning to emerge within global capitalist order. It is due to these new cores that over the period 1970-2006, annual real global GDP growth has usually approximated 4 percent and in only five years out of these 36 has global real GDP growth been below the average rate of growth of world population. (IMF2007). IMF data shows that there were five recessions during 1970-2006 but all of them were brief and shallow. Again this may be attributed to the astonishing resilience of the newly industrializing 'emergent' economies especially China whose growth rate did not slacken perceptibly even during the East Asia crises of $1997-1998^{1}$. Old core countries based multinationals have benefited from the resilience of the new core countries and their rates of profits in countries such as China are often reported to be higher than in the old core countries ${ }^{2}$. In China for example "from 1998 to 2006 profits of industrial enterprises soared from 2 percent of GDP to over 10 percent" (Lardy 2007). The World Bank attributes strong profit growth in China to improvements in efficiency and labour productivity (World Bank 2007).

It is sometimes asserted that the Chinese economy is not yet large enough to serve as a locomotive for pulling the global capitalist system out of the sort of recession it experienced in 2007-09. In 2008 China's share of world GDP measured at current US $\$$ an exchange rate was only about 6 percent. But this is a serious underestimate due to the holding down of the $\$-$ Yuan exchange rate by the Chinese government. In purchasing power parity terms the share of the. Chinese economy in world GDP was about 11 percent in 2007 (World Bank 2008). China has been growing at an annual average rate of about 10 percent during 1978-2008 and the investment to GDP ratio exceeds 40 percent in most years ${ }^{3}$. Over a fifth of global fixed capital formation now takes place in China. Estimates of profits remitted by foreign companies from China to metropolitan 'home' countries vary widely but are substantial and offset to some extent the reduction of profits in these countries due to enhanced Chinese competitiveness. 
Profits earned in 2006 in China by US based multinationals exceeded the total profits they earned during the 1990 s decade $^{4}$. China remains however basically a domestic demand oriented economy. The World Bank (2007) estimates that during 2006-2007 over three quarters of Chinese GDP growth was accounted for by expansion in domestic demand. The import to consumption ratio is rising rapidly in China however and booming Chinese imports contribute significantly to global corporate profitability. In any case Chinese exports are more of a "threat" to the developing countries than they are to the West. In 20007 China's exports to India, Brazil and Russia exceeded China's exports to America ${ }^{6}$.

To see the 2007-2009 credit crunch as a typical Marx-Minsky crisis is anyhow misleading. Corporate profits have recovered significantly during 2001-2007 and the main industrial companies in most metropolitan countries have reduced debt and built up cash reserves. Corporate savings are at historical high levels and investors are looking for relatively low risk, high returns profits. Can China be capital's next global metropole capable of sustaining high levels of capital accumulation not only in China but throughout the world?

The answer to this question is not yet clear. First it must be noted that China is experiencing many of the problems of the West. Thus bad debt accumulation is as much if not more a Chinese as it is an American phenomenon. Moreover most studies (O' Hara 2006, Lavena and Fan 2008) show that though corporate profitability remains high in China it has been falling during 1990 to 2003. The capital - output ratio is also rising and the excess of saving over investment is growing as China's external reserves are built up in America and Europe. Chinese population is also ageing as rapidly as the population of Europe and America. In his report to the 2007 National People's Congress the Chinese Prime Minister. Wen Jiabao described China's growth as "unstable, unbalanced, uncontrollable and unsustainable"7.

But all capitalist booms are "unsustainable, unbalanced, uncontrollable" and in the long run "unsustainable". The current China boom has lasted almost three decades and there may well be a slowing down of output and investment growth in the forseeable future. However even if we concede that China is not yet the most powerful locomotive which can pull global capitalism from its present crises China may well have the potential to play this sort of a role in the future. The next section outlines some constraints limiting China's potential as a hegemon for global capitalist order.

\section{Why China Is Perhaps Not Yet Ready.}

Three decades have passed since the advent of the counter revaluation which partly overthrew Maoism in China. In 1978 Deng Xiaoping announced the famous 'Four Modernizations'. These "modernizations" focused upon opening up China to foreign investment and trade in a manner which would enable China's external sector to serve 
as a key growth stimulant for the national economy. What is usually not recognized as Hutton (2007) asserts - is that this did not involve a major withdrawer of the state from the economy: Local government controlled and managed Town and Village Enterprises (TVEs) flourished throughout the 1980s and it was their burgeoning profitability which attracted much foreign investment to China during the 1990s. No major industrial enterprise was privatized until 1997. Even in 2001 the state had control of 84 percent of companies listed on the Beijing Stock Exchange (Hutton 2007 p50). This reveals the connections between the current modernization and the Maoist past. The modernization built upon the success of the Maoist period especially as far as institutional redesign was concerned. Industrial decentralization undertaken by the Maoist regime was crucial to the structuring of the TVEs in the 1980s.

Envisaging China's emergence as global capital's hegemonic state requires an evaluation of the probability of the continuing balancing of the state dominance of the Chinese economy with the external sector's role as primary growth stimulant. During the past decade (1997-2007) much of export growth has been undertaken by foreign producers - American, European, Japanese - located in China's Sunbelt. Export growth at current levels thus requires sustaining a corresponding growth of foreign production capacity in China ${ }^{8}$.

Much of this increase in production will have to be financed by reinvested profits and borrowings in China. Moreover China's export growth is also likely to fall as major export markets contract and domestic demand orientation of the Chinese economy must therefore increase if China's output growth is to be sustained at current rates.

Increased domestic demand orientedness ${ }^{9}$ is also necessary because of the rapid upgrading of the technological skills of the Chinese work force (which remains low by international standards) unskilled "surplus" low paid workers central to export processing work are no longer easily available (Freshman 2006 p174).

The structural transformation that China has achieved during 1978-2008 refutes the argument that a comprehensive embrace of what Hutton (2007 p18) calls "Enlightenment values" has been necessary (Arrghari 2007) certainly more "economic and social freedom, ${ }^{, 10}$ is now available to the ordinary Chinese citizen than was the case under Mao. But political power remains firmly in the hands of the Communist Party and the 1989 uprising was almost a complete failure. So far China has followed the path of the first generation Asian tigers - Taiwan, South Korea and Singapore - which achieved growth by combining state dominance of the economy, single party authoritarianism and selective encouragement of market initiatives (Wade 1989).

Western exporters have found it extremely difficult to penetrate the domestic Chinese markets. Nine years have passed since China's accession to the WTO but this has had very little impact on China's imports from the West (Freshman 2006 p43-46). 
This is partly because of the grossly inequalizing character of Chinese growth throughout the modernization era Croll (2006) cites a 2005 government survey which calculated in that year that the top 10 percent of China's population owned 45 percent of the country's personal wealth while the poorest 10 percent owned only 1.4 percent. Moreover Croll finds that inequality is increasing so that downward social mobility (from middle to lower income groups) is more common than upward mobility (Croll 2006 p22). Since the mid 1980s the income gap between town and country has widened and in 2003 a large proportion of peasants (estimated variously at 23 to 50 percent of the rural population) lived at or below the official poverty line (Croll 2006 p71-81). Regional inequality is also very high in China with the Muslim North Western peasant regions desperately poor.

The gap between the rich and the poor is greatest in the cities. According to Croll between 9 to 12 percent of urban residents lived below the officially defined poverty line in 2003. As Croll emphases these estimates exclude the tens of millions of rural "temporary" migrants to the cities (2006 p137). In Croll's view income disparities constitute the single most important constraint on the growth of China's mass consumption.

Growing income and asset disparities have produced mass protest and unrest specially from peasants who still number over 350 million in China: since the early 1990s they have been hurt both by declining agricultural terms of trade and by exorbitant local administration taxes. Government corruption is rampant in the countryside $\left(\mathrm{O}^{\prime}\right.$ Brian et al 2006) ${ }^{11}$. Local taxes are usually illegal (not sanctioned by the state). The central government often sees these taxes as harmful for they reduce farm output. Since about 2000 per capita food production has been on a declining trend exacerbating inflation. But the central government's ability to control local administrations is limited. Protests against local taxes usually seek to provoke central government authority to act against that of local administration, mobilizing around the time honored. Chinese adage "the Emperor is just but his officials are corrupt" and these protests should not be seen as a protest against the whole system. ${ }^{12}$

Peasant unrest has led to the migration of between 110 to 150 million people to the cities (Hutton 2007 p106). They perform slave labour in atrocious conditions (Chan 2001). Since the mid 1990s between 50 to 80 million workers have been made redundant due to the restructuring of state enterprise (Croll $2006 \mathrm{p} 110-114)^{13}$. Workers protest movements have been sustained by support from both rural migrants and resident ex-employees of state owned enterprises and have risen dramatically since the mid 1990s (Chiang 2007) Factory closures have not been resisted and protests concentrate on inadequacy of redundancy payments. Moreover there were very few instances of plant level resistance spreading through out the city or region. However these protests were successful in achieving major pension and redundancy payment reform which was enacted by 2001 and since that year there have been no major resistance movements of laid off workers. 
The anti redundancy movements were concentrated in the "Rust Belt" dominated by heavy capital goods making plants. Since 2001 a wave of strikes have also hit the "Sun Belt" - the home of the new expanding export oriented firms. The "new wave" strikes are also defensive ${ }^{14}$. They are best seen as demands for the effective implementation of the existing labour law. Thus these straggles are not against capitalism but against capitalists who violate capitalist laws to compensate for declining profit rates ${ }^{15}$. The working class protesters in cities such as Shenzen are trying to use the power of the capitalist state to discipline capitalist enterprises. Workers protests against systemic non implementation of capitalist laws is tolerated as long as it remains "spontaneous" plant specific, non political and does not involve the organization of independent ${ }^{16}$ unions. In my view there is no evidence that the "new wave" unrest seriously threatens the dominance of the existing governance system. I see the Chinese incumbent regime as headed for the gradual piece meal introduction of the type of social democratic reforms that were introduced in Germany during the last decade of the nineteenth and the first decade of the twentieth centaury.

China is now a full fledged non liberal capitalist economy like - late nineteenth century Germany and Japan - with the commodification of land and labour the inter mingling of corporate and state property and the systemic dominance of finance capital ${ }^{17}$. China has also succeeded in developing an authoritarian capitalist state structure during the first decade after the introduction of the 'Four modernizations' which led to the defeats of the imperialist funded 1989 unrest and avoided the type of implosion of state and Party that the USSR and East Europe experienced ${ }^{18}$.

The economic power of the state is reflected in the continuing strength of both state owned enterprises and local governments which own a great deal of financial capital and are major players in the land market. State enterprises are seen as the development arms of the governments. Unlike foreign firms and joint ventures state firms produce mainly for the domestic market and not for exports. Since 1998 reducing dependence on foreign markets and increasing production to serve domestic demand has been a major objective of state economic policy (Yun-Wang 2005) ${ }^{\mathbf{1 9}}$. Infrastructure and info structure investment by the state is specifically directed to this end. During 1990-2006 over 90 percent of investment in China has been domestic market oriented and rates of return to domestic investment have been exceptionally high (Yun-Wang 2005). The Chinese labour force - specially that employed in domestic and state enterprise - has been ruthlessly exploited and in a typical year more than 40 percent of GDP is absorbed in capital formation.

Many of China's new billionaires ${ }^{20}$ have emerged from the ranks of the state bureaucracy and maintain their links with both state and party apparatuses. They have been the major beneficiaries of state enterprise privatization. Close links with the Party is "good for business" Managers of state enterprises and banks, like their German and 
Japanese predecessors, function as state capitalists - many of them own shares in workers co-operative and state corporations. The banking system - which is still 80 percent state owned ${ }^{21}$ - is a very generous source of cheap investment finance (specially for local government ventures). Over 50 percent of bank financing is for state owned enterprises $^{22}$. Very generous lending has burdened the Chinese banking system with a high level of bad debt. (The infection ratio was rumored to be almost 50 percent in 1999-2000). This accentuates the crises management role of the state.

Economic liberalization has been a state project in China since 1978- as it was in Bismarck's Germany. The governing role of the Communist Party and the State Council remains crucial in the whole process. The form of state governance has been restructured to foster bourgeois dominance of the social order (and some would say also of the state form). The state has not shrunk in the process - quite the contrary it has "sprawled" and the complexly of state social intervention has increased enormously.

The essence of this "state sprawl" is the structuring of a new relationship between central and local government. The central government remains firmly in command and market and society liberalization occurs not spontaneously but in response to the promulgation of new laws by the state. This has been accompanied by a downward shifting of state power. Autonomy of local - specially city - governments has been expanded significantly. Fictionalization of the Party seems to have increased in response to straggles for preserving or enhancing autonomy of different tiers of local government ${ }^{23}$. Big city factions seem to have acquired particular strength within the Party (Wu 2003). Local government authorities - at different tiers - city, provincial and county - are China's principal "overseers of development". They have been given specific powers - including seizure of land and sanctioning of infra structure facilities - to foster "growth enhancing partnerships". State and party officials at the local level are encouraged to play an entrepreneurial role: They have stakes in private businesses and serve as managerial directors of state enterprises. Party cadres are assessed for promotion within the Party on the basis of their effective participation in development projects.

Local governments also enjoy an enhanced level of fiscal autonomy - their revenue depends more on local rents and taxes then on central government subventions. China is now one of the most decentralized states in the world in a fiscal sense. A vital source of local revenue is business taxes and profits and sales of state firms. The local state and Party have become agents of particular capitals.

This is also at last partly true of the central government and Party apparatus. Central government and Party officials protect— and benefit from protecting — particular capitalist interests. Since 2002 private businessmen have been admitted into the Party and they are now said to constitute the majority of its national leadership (Dickson 2005). But like in Bismarckian Germany and Meiji Japan the ultimate legitimacy of the 
central state (and Party) derives from its ability to ensure capitalist development in China as a whole - not just the advancement of particular (regional and corporate) capitals. The central state and Party remain committed to a widespread diffusion of the benefits of capitalist development throughout China and periodically launch "campaigns against corruption" to address the most rampant injustices.

\section{Can China bear the White Man's Burden?}

China cannot be the main force behind capitalist revival in the present downturn ${ }^{24}$. The weight of Chinese production consumption and finance in global aggregates is simply not large enough today to enable China to play a leading role in world capitalist revival. Indeed Chinese growth may itself decelerate due to the global recession since China remains dependent on both exports and imports as growth stimulants because of her low technological development and distributional constraints on the expansion of domestic demand: Moreover since multinationals and not state owned firms are the main driving force behind Chinese export growth, setbacks in headquarter countries (U.S, Europe, Japan etc). may reduce foreign investment in China thus restricting that country's export growth.

This does not of course mean that China cannot play an important role in global capitalist revival. Obviously it can, since it continues to grow at least three times faster than the metropolitan capitalist countries and is therefore an increasingly significant absorber of "surplus" 25 capitalist production and savings. The question therefore is, can Chinese high growth be sustained for a sufficiently long period to enable it to eventually replace America as the global capitalist hegemon as America replaced Britain in the twentieth century? There is also the question; does the Party leadership seek to play a systemic hegemonic role.

In the case of the United States the main stimulant to development has been the growth of domestic demand. The Chinese government recognizes that increased domestic demand orientation is crucial both for growth sustenance and for reducing macroeconomic instability and sectoral imbalances (Croll 2006 Chapter 8). The main constraint on the growth of domestic consumption specially for the types of goods that China itself produces is the increasingly unequal distribution of income and wealth leading to the concentration of purchasing power in the hands of groups with relatively high propensity to import and high propensity to $\mathrm{save}^{26}$. But is prioritizing domestic demand growth compatible. with the political agenda of the post Maoist modernizing Communist Party (CCP).

The Post Maoist CCP has built an "absolutist" capitalist state ${ }^{27}$. Table1 contrasts liberal and absolutist capitalist state structures. 
Table 1: Liberal and Absolutist Capitalist State Structures.

\begin{tabular}{|c|c|c|}
\hline Structural Element & Liberal Capitalist State & Absolutist Capitalist State \\
\hline Tasks & $\begin{array}{l}\text { I. Establishing market dominance } \\
\text { over society. } \\
\text { II. Separation of public and private } \\
\text { spheres of society. }\end{array}$ & $\begin{array}{l}\text { I. Expansion of the public sphere. } \\
\text { II. Maintaining a balance between plan } \\
\text { and market authority. } \\
\text { III.Private atomization. }\end{array}$ \\
\hline Personal recruitment & $\begin{array}{l}\text { Intellectual and personal qualities } \\
\text { enabling effective representation } \\
\text { leading to an absorption of the will } \\
\text { of all into the general will } \mathbf{2 8}^{\text {. }}\end{array}$ & $\begin{array}{l}\text { Technical and mobilization ability } \\
\text { to ensure / enhance mass acceptance } \\
\text { of the governing group's conception } \\
\text { of the general will }{ }^{29} \text {. }\end{array}$ \\
\hline Resources & Taxation & Public investment Taxation Price setting. \\
\hline Modus Vivendi & Impersonal rule application, Legalism. & $\begin{array}{l}\text { Administrative decree, governing groups } \\
\text { bargaining and factionalization, selective } \\
\text { subsidization and penalization }\end{array}$ \\
\hline Patterning of authority & $\begin{array}{l}\text { I. Separation of executive legislative } \\
\text { and judicial authority and apparatus } \\
\text { II. Bureaucratic hierchy }\end{array}$ & $\begin{array}{l}\text { I. Executive dominance. } \\
\text { II. Ad hoc interventions and initiatives of } \\
\text { apex political authority. } \\
\text { III. Party organization at mass level. }\end{array}$ \\
\hline $\begin{array}{l}\text { Output } \\
\text { Domestic policy }\end{array}$ & $\begin{array}{l}\text { I. Legal procedure unification. } \\
\text { II. Development of the market. }\end{array}$ & $\begin{array}{l}\text { I. Administrative regulation (also) of } \\
\text { market forces. } \\
\text { II. Development of productive forces. }\end{array}$ \\
\hline Output Foreign policy & $\begin{array}{l}\text { International co-operation and } \\
\text { competition and promotion of } \\
\text { global market strength of nationally } \\
\text { based capital. War unending to } \\
\text { sustain competitive advantages. }\end{array}$ & $\begin{array}{l}\text { I. Imperialist expansion for preferential } \\
\text { access to markets and recourses } \\
\text { II. Promotion of interests of national } \\
\text { capital through international bargaining. }\end{array}$ \\
\hline $\begin{array}{l}\text { Output } \\
\text { State society relationship }\end{array}$ & $\begin{array}{l}\text { Formal separation of state officials } \\
\text { from social organization }\end{array}$ & $\begin{array}{l}\text { I. Merger of public and private } \\
\text { bureaucracies } \\
\text { II. State (official) penetration of mass } \\
\text { organizations. }\end{array}$ \\
\hline Social spirit & Discipline & Technical flexibility Mass mobilization \\
\hline
\end{tabular}




\section{Source Based on and derived from Poulantzis (1973) and Theoborn (2006)}

China does not of course fit neatly into our "absolutist" capitalist state category which is no more than a heuristic device. Nevertheless China is significantly closer to the "absolutist" than to the "liberal" capitalist category.

China is no longer "a dictatorship of the proletariat" ${ }^{30}$ but it is a dictatorship nevertheless and the Maoist political programme and infrastructure has been modified but not abandoned. I hold this view because.

- The state has "sprawled" - its sphere of social intervention has expanded not shrunk.

- Planning has not been abandoned. The state seeks to govern the market not just regulate it.

- The state promotes social atomization of individuals through intensified competition at all levels.

- Mass mobilization "campaigns" play as important role in enhancing state legitimacy.

- Public investment remains large and state firms continue to produce a large proportion of total output.

- Factionalization at all party and government levels and bargaining at the top largely determine political outcomes.

- Party declarations and ad hoc administrative decrees are major instruments for policy articulation.

- Modernization / development is the raison d'etre of CCP's monopoly of political power.

- Promotion of Chinese economic interests is the principle objective pursued by Chinese foreign policy.

- $\quad$ There is wide spread merger of state and private sector bureaucracies and continued party presence at factory level.

Can such a state aspire to and achieve hegemonic status within global capitalist order? One broadly similar state, Bismarck's Germany tried to achieve global hegemonic 
status and was defeated by America. In my view it is unlikely that China will embrace similar ambitious for China does not need the "living space" access to which determined Germany's political strategy during 1871-1944. Moreover the difference in the military capacity of China and the United State is so large that contesting US global hegemony militaristically is currently unlikely to be seen as a realistic policy objective by the CC.

Crucial to understanding Chinese strategic ambitions is a grasp of the relationship that has developed between local and central government in post Maoist China - China is today one of the most fiscally and administratively decentralized states within global capitalist order. The executive authority of local government tiers has expanded enormously since 1979. "State sprawl" involves a deliberate and planned shift of executive authority to local government tiers which are seen as the principle executors of public development policy.

However this expansion of the executive authority of local governments has not weakened the central state institutions. This is because modernization / liberalization is not a spontaneous process in China today ${ }^{31}$. It is a central state project. The role of the Communist Party and the State Council remains crucial in determining the pace and direction of capitalist modernization. The Communist Party deliberately and in a planned manner facilities the embourgment of economy and society. As noted above since 2002 businessman have been admitted into the Party and the ranks of Chinese billionaires have been swelled by ex bureaucrats exploiting links with local and central party and state apparatuses. Both local and central state structures have extensive links with multinationals and factional straggles within the Party and state institutions often reflect a clash of business interests.

The Communist Party now represents the bourgeois and like Bismarck's Germany, China has become a "dictatorship of the bourgeoisie". But the bourgeois are a small minority and prioritizing their interests exacerbates income and asset distributional inequities. The role of the Communist Party and the central state leadership remains crucial in (a) reinterpreting ideological discourse to legitimate socio - economic embourgment and the distributional inequalities it entails. (b) ameliorating the worst consequences of these inequities and spreading the benefits of development throughout China to facilitate the growth of domestic demand.

The continued need for central state policy dominance has been widely recognized throughout China. China has been a unified state since 221BC when the Qin dynasty put an end to the 'Warring States' era (475 BC to $225 \mathrm{BC}$ ). This period and the proceeding one (770 $\mathrm{BC}$ to $476 \mathrm{BC})$. $^{32}$ when China was divided into several independent states is widely regarded as disastrous in China as is the period of the 'war lords' characterizing the later years of the Qing dynasty (1644-1911) and the period of nationalist 
rule (1911-1949). Authors such as Bray (1984) particularly stress the adverse impact of the decline of local trade which accompanied state structure fragmentation in China, Self governing local communities have usually not flourished in China ( $\mathrm{Xu}$ and $\mathrm{Wu}$ 2001). It is not surprising that while local governments struggle against each other for greater central government patronage and privileges they do not straggle for restricting the authority of the central government institutions or the Party ${ }^{33}$.

The authority of the central Chinese state is not being undermined by increased local autonomy and there are no credible threats to Chinese unity. The exception to this may be Tibet and the Muslim dominated provinces of Xinjiang, Qinghain, Gansu and perhaps Sichuan where resentment against Chinese rule is increasingly widespread and where China continues to pursue a brutally repressive policy for the last six decades: In these province the local population is being turned into a minority and is systematically denied access to material resources and employment opportunities (French 2003). In the Muslim provinces and in Tibet large segments of the local population have since 2006 been herded into reservation settlements like those imposed on Red Indians and Aborigines in America and Australia, These people are without employment and ravaged by disease and alcoholism. This facilitates Chinese exploitation of the mineral and agricultural wealth of these regions (Hore 2007 p83).

Occupation of the Muslim provinces and of Tibet is justified on grounds of imperialist conquest (by the Yuan, Ming and Qing dynasties) The People's Army and local state forces continue to act as an occupation force in the Muslim provinces and in Tibet. Unlike the rest of China mass resistance in the Muslim provinces is against Chinese state authority and not for combating systemic corruption ${ }^{33}$.

Together the Muslim majority and Tibetan majority provinces constitute one third of China's land mass ${ }^{34}$. Maintaining control of these areas is an important Chinese imperialist policy objective ${ }^{35}$. But beyond this China has no expansionist ambitions. Nor is it likely to have and hegemonic ambitions as a large as the disparity in terms of military strength with the United States remains huge.

Therefore China is not a contender for the role of global hegemon as Germany was in the first decade of the twentieth century. It is quite happy to play second fiddle to America. It has invested hundreds of billions of dollars in American government treasury bills. It actively supports the American war of terror in Afghanistan and Iraq and endorses the American strategy in the Middle East and in Pakistan. As a member of WTO and other inter governmental organizations it continues to adopt and adapt Americana's economic standards and procedures. China is not ready to shoulder the white man's burden nor is the White Man willing to transfer this burden to yellow shoulders. 


\section{Notes}

1. The recovery of the other East Asian economies — South Korea, Malaysia and Thailand — was also astonishingly rapid

2. Evidence on this is mainly conjectural for estimates of corporate profitability in America (for example) exclude profits of these companies from overseas operations.

3. Figures in this paragraph are from World Development Indicators, an annual publication of the World Bank. (Various years).

4. U.S Today $25^{\text {th }}$ October 2007.

5. To conceive of Chinese exports as a "threat" to global profitability is a mercantilist perspective Chinese exports may alternatively be seen as stimulating both consumption and investment growth specially in developing countries.

6. The Economist. $6^{\text {th }}$ March 2008.

7. Reported in Financial Times $13^{\text {th }}$ March 2007.

8. Hutton (2007 p31) maintains that if Chinese exports maintain their current growth over the next fifteen years Western multinationals already in China would have to maintain a rate of growth of output which has to be six or seven times higher than the rate of growth of their domestic markets.

9. Thus is already occurring since as we noted earlier only a quarter of Chine's GDP growth during 2006-2007 was due to export expansion.

10. These freedoms most significantly include the right to strike specially for state workers.

11. O; Brian (2006) says that these were the most serious peasant protests since the time of the Great Leap Forward

12. It needs to be stressed that there was no mans support of the1989 uprising. However in 2003 Chen and Wu published their famous Will the Boat Sink the Water detailing peasant oppression. It was banned throughout China. It sold an estimated 12 million copies over eighteen months and was seen as "inciting sedition" by the government.

13. In some Muslim North Eastern regions unemployment is said to have reached 8 percent in 2000 (Becker 2001 p 38-48). 
14. That is they protest denial of workers' rights as defined by existing laws (especially failure to pay wages on time).

15. Profits in Chinese export oriented industry have been failing since 2002. Due to over production and intensified competition.

16. That is non Communist Party dominated unions.

17. This trend is however not yet complete.

18. This is not to deny that much of China remains pre capitalist. Capitalist property and finance has not penetrated many parts of the economy and state authority is not fully articulated as an agent of capital accumulation.

19. Although exports have risen significantly since Chine's entry into the WTO in 2000 and the export to GDP ratio stood at 37 percent in 2007.

20. In 2007 there were estimated to be seven (dollar) billionaires and about 300,000 (dollar) millionaires in China (Walker and Buck 2007 p54).

21. Although it is being cautiously privatized.

22. State bank financing played a major role in preventing collapse of state enterprise during 2000-2004.

23. Expansion of the power of metropolitan cities to annex neighborhood smaller cities seems to be particularly contentious.

24. That is the 2007-2009 recession.

25. "Surplus" in the sense that effective demand does not exist for their purchase

26. This is also a major cause of the relative unprofitability of state owned firms and Town and Village Enterprises (as against foreign firms) which produce mainly for the domestic market and not for exports.

27. The term is Perry Anderson's. See his classic study (1971). However our conception of the "absolutist state" differs significantly from Perry Anderson's conception.

28. The liberal capitalist state most ensure that the majority of the citizenry ('the will of all') continues to endorse. 'The general will' which legitimizes capital accumulation as the socially supreme end in itself. 
29. Increasingly publicly sanctioned market transactions are presumed to define the general will. The liberal capitalist state seeks to protect and promote (through law and administration) specific market conceptions of the general will. In absolutist capitalist states the governing group (s) defines the general will on the basis of a prioritized group (usually nation or class) interest. This usually leads to a greater or lesser, increasing or decreasing subordination of the market to the plan. For a classic discussion of the relation of the will of all to the general will see Rousseau (1984). For a justification of conserving of the general will as the will to perpetually priorities capital accumulation as the socially supreme end in itself see Ansari and Arshad (2006 chp2).

30. I have argued elsewhere (1990 sec11) that the "dictatorship of the proletariat" is also a capitalist state form on the grounds that the ultimate objective perused by the dictatorship of the proletariat is material abundance and this legtimates the prioritization of (long run) capital accumulation as an end in itself.

31. As it was in America in the $19^{\text {th }}$ century when state governments contested federal functional authority.

32. Called the Spring and Autumn period of China's history.

33. This is also true of the peasant and worker protest movements which straggle usually on the bases of the platform "The Emperor is just but his officials are corrupt". They resent the abuse of authority and do not regard the constituted state authority as unjust or inefficient or illegitimate.

34. But they account for only about 2 percent of China's population.

35. An objective increasingly difficult to achieve due to growing popular resistance despite the absence of any significant external support for the Muslim resistance.

\section{REFERENCES}

Anderson. P (1971) Lineages of the Absolutist State London Verso.

Ansari. J (1990) "Mutiny in East Europe and Some Lessons for Islamic Revolutionaries" Universal Message Vol. 11 No 3-4 pp 49-91-

Ansari. J. A and Arshad. Z (2006). Business Ethics in Pakistan Karachi. Royal

Arrghiri G (2007). Adam Smith in Beijing London Verso

Becker J. (2001) The Chinese London John Murray.

Bray F (1984) Science and Civilization In China Vol 16 Cambridge, Cambridge University Press.

Chan A (2001) China’s Workers Under Attack New York Sharp.

Chan. G and Wu.C (2006) Will the Boat Sink the Water New York. Public Affairs (English Translation) 
Chiang K.L (2007) Against the Law, Berkley University of California. Dickson. B (2005) Red Capitalism in China, Harvard University Press Cambridge Mass. French. H (2003) Tibet! Tibet! New York, Harper Frishman T (2006) China Inc, New York Basic Books Croll. E (2006) China's New Consumers, London Rutledge

Hore. C (2007) "China Tibet and the Left", International Socialism No119-pp75-92 Hutton W. (2007) The Writing on the Wall, New York, Croom Helm IMF (2007) World Economics Outlook 2007, Washington.

Lardy N (2007) China relaunching economic growth. institute.org/publications/papers/lardy $0507 \mathrm{pdf}$.

Lavena L. and R. Fan (2008) "Diverging patterns of profitability and growth in China and India during 1980-2003", World Development Vol. 36 No5.

O’ Brian P. etal (2006) Regional Resistance in Rural China Cambridge, Cambridge University Press.

O' Hara P (2006) “A Chinese Social Structure for Accumulation”, Review of Radical Political Economy, Vol 38 No3.

Pooulantzis. N (1973) State, Classes and Power’ London New Left Books.

Rousseau J.J (1984) The Social Contract, London, Rutledge.

Theoborn. G (2006) What Does the Ruling Class Do when it Rules? London Verso.

Wade R. (1989) Governing the Market, London Pinter.

Walker. W and Buck. D (2000) “The Chinese Road”, New Left Review 11:42p41-70

World Bank (2007) China Quarterly Update, September, Washington.

World Bank (2008), World Development Indicators, Washington.

Wu. F (2003) "Globalization, place, promotion and urban development in Shanghai", Journal of Urban Affairs Vol25 No1 p32-61.

Xu. D and Wu. C (2000), Chinese Capitalism 1522-1840, London Macmillan

Yung-Wang, S. (2008), The Emergence of Greater China, Wiley, New York. 